\author{
О ВКЛАДЕ ТАТАРСКОГО ТЮРКОЛОГА В ОРИЕНТАЛИСТИКУ \\ (РЕЦЕНЗИЯ НА МОНОГРАФИЮ ПРОФЕССОРА М. Х. БАКИРОВА \\ «ПРОТОТЮРКИ: ИЗНАЧАЛЬНАЯ ПРАРОДИНА, РАННИЕ ПЛЕМЕНА \\ И ЯЗЫК, ИСТОРИЯ И ЭТНОКУЛЬТУРА». - КАЗАНЬ, 2018. - 464 С.)
}

(C) Тариел Азертюрк

\author{
ON THE CONTRIBUTION OF THE TATAR TURKOLOGIST TO \\ ORIENTALISM \\ (REVIEW OF PROFESSOR M. BAKIROV'S MONOGRAPH 'PROTO \\ TURKS: ORIGINAL HOMELAND, EARLY TRIBES AND LANGUAGE, \\ HISTORY AND ETHNOCULTURE". - KAZAN, 2018. - 464 p.)
}

\title{
Tariel Azerturk
}

Рецензируемая монография профессоратюрколога М. Х. Бакирова является весьма важным событием в современной ориенталистике, поскольку прибавляет уникальный и пионерский в своем роде труд к малочисленному корпусу работ по этногенезу, этнокультуре и этнолингвистике ранних тюрков. Эта книга содержит разработку новой и оригинальной концепции глобального характера, согласно которой тюркское языковое единство сложилось за счет смешения и слияния лексики и признаков исторической грамматики родственных (агглютинативных) и отчасти неродственных (флективных) языков благодаря их длительному и интенсивному взаимодействию в составе единого ареального союза на Ближнем и Переднеазиатском Востоке.

Зарождающий прототюркский язык, как утверждает автор, находился с другими языками этого ареала в состоянии культурно-контактного родства и формировался в составе шумероафразийско-индоевропейско-дравидо-загросского языкового союза. Иначе говоря, прототюркский языковой массив по отношению к другим языкам Ближнего Востока выступал в качестве изначального «среднеземноморского субстрата» и представлял из себя обширный диалектный массив тюрко-алтайского типа. Такой подход в части хронологии смыкается с выводом разработчика ностратической теории В. М. ИлличаСвитыча о том, что «алтайская (по сути прототюркская. - М. Б.) общность значительно древнее уральской, дравидийской, индоевропейской, картвельской и семито-хамитской и наиболее близка к ностратической» [Иллич-Свитыч, с. 69].

По концептуальному заключению М. Бакирова, которое созвучно со взглядами здравомыслящих языковедов, алтайское языковое единство фактически образовалось после миграции прототюрков на восток и смежного соседства и взаимодействия их с другими так называемыми алтайскими языками. Монголы, тунгусо-маньчжуры, тем более японцы и корейцы общие и схожие с тюрками лексемы приняли от их носителей эстафетообразно, то есть через посредство соседних языков.

Но, как утверждает автор, теории как ностратической, так и индоевропейской макросемей не в силах разъяснить поразительную общность собранной и систематизированной им базовой и культурной лексики ранних тюрков, которая связана с мертвыми и архаичными языками древнего Ближневосточного ареала. Ибо обе эти теории необоснованно отрывают прототюрков от их первоначального местопребывания и переносят его на восточную территорию: либо в Центральную Азию, либо - в лучшем случае - в Среднюю Азию. При этом, подчеркивает татарский тюрколог, делается упрощенный и односторонний вывод о том, что предки тюрков сходные слова якобы заимствовали напрямую, либо через промежуточные диалекты из западно-ностратических языков или же главным образом из индоевропейских (включая индоиранских) народов, 
эмигрировавших после распада Ближневосточного языкового союза на восток.

Возникает парадоксальная ситуация: в создании базового лексического словаря предки тюрков сами якобы не участвовали, потому что, по господствующей концепции индоевропеизма и индоиранизма, схожие лексемы рассматриваются как результат миграции индоевропейцев, а также как следствие «ползущей ностратизации» (удачный термин самого автора). Но такая концепция совершенно не согласуется с реконструируемым исследователем лексико-семантическим, отчасти этимологическим сравнительным словарем Ближнего Востока, включающим в себя, помимо общего лексического корпуса, также и многочисленные архетипы из неиндоевропейских и неностратических языков.

Первая часть книги называется «Лексикосемантический сравнительный словарь», составленный автором на материале выявленных генетико-контактных изоглосс из мертвых и древних языков Ближнего Востока, параллельных с древним лексическим слоем тюркоязычного мира. Кроме индоевропейских и картвельских макроязыковых семей, в нем представлены также языки неиндоевропейского и неиранского склада и непременно с агглютинативным морфологическим строем, а именно кутии (гутии), касситы, эламиты. Они составляли родственную между собой группу, условно называемую загросской или каспийской. Языкам этого же строя относились еще и шумеры, субары, дравиды, а также переселившаяся из Передней Азии в Африку хамитская группа (кушиты, чады, берберы, древние египтяне).

Надо особо отметить, что прототюркский языковой массив, по своеобразной концепции татарского тюрколога, формировался в силу длительного сожительства и интеграции (сближения и слияния) как раз из этих языков, но одновременно ряд лексических архетипов ранние тюрки создавали в процессе взаимообщения с мертвыми и индоевропейскими племенами и народностями совместно, либо даже заимствовали непосредственно у них. По мере сложения и развития производящего хозяйства, включая кочевое скотоводство мелкого и крупного рогатого скота, наши предки постепенно отпочковались от ареального языкового союза и самый ранний лексический слой унесли с собой на Восток - в Среднюю и Центральную Азию, в регион СаяноАлтая и степные просторы Сибири. Постановка и вердикт по вопросу глоттогонии тюркского языка в таком ракурсе вполне правомерны и подкупают своей аргументированностью.
Весьма примечательно, что вопрос о хронологическом дальнем контактно-генетическом родстве ранних тюрков с древними афроазиатско-хамитскими языками, потомки которых и ныне живут в Северной и Центральной Африке, ставится в ориенталистике впервые. При этом, что очень важно, М. Бакиров из хамитских языков выделяет уцелевшие архетипы, обозначающие первопредметы и изначальную примитивную форму какой-либо деятельности, которые в дальнейшем стали основой для выражения видоизменений в тех же сферах. Таковы: ка / кар (кan) - сосуд из листьев $\rightarrow$ деревянная чаша $\rightarrow$ горшок, кувшин $\rightarrow$ бурдюк, куль; ка (сосуд) + bак (тыква, бутыль) - сосуд-тыква $\rightarrow$ посуда $\rightarrow$ $\kappa a+з a н$ - сосуд рода (племени) > zan / zon (др.тюрк.) - родовой коллектив, племя, народ; $h b /$ $h a b a-$ мотыжить, мотыга $\rightarrow$ hb - плуг $\rightarrow$ saban «то же», sak - заостренный колышек, тычковая обработка земли // sak - мотыжить, пахать, обрабатывать землю $>$ saka - сеять $\rightarrow$ haha - coха / сука (деревянный плуг). Все эти поразительные факты восстанавливают истоки известных нам культурных явлений или действий, которые уже давно забыты и указывают на географический регион, откуда они берут начало.

Самое главное, такие вот удивительные субстратные слова совместно с другими лексическими параллелями, которые в общей сложности доходят чуть-ли не до тысячи единиц, подтверждают правоту пробивающей себе дорогу глобальной идеи о первоначальной ближневосточной прародине палеотюрков. Ибо слово - это, как принято оценивать в научных кругах, самый долговечный и надежный свидетель и памятник истории, причем чуть ли не каждое слово или лексический корень-основа в словнике за счет параллелей из контактных и генетических родственных языков наращивается до объемного лексического гнезда и сопровождается познавательной словарной статьей. Такая форма составления сравнительного словаря воссоздает перед нами генезис и эволюционную картину, включая межэтнические преемственные связи, определенной части основного и культурного лексического фонда тюркского мира.

Вторая часть монографии названа «Этническая идентификация прото- и пратюркского мира на основе комплексных признаков». Очень важно и показательно то, что в этом разделе исследователь концепцию о самой ранней ближневосточной прародине наших дальних предков рассматривает дифференциально: вернее, разбивая людской и этнополитический мир Ближнего и Переднеазиатского Востока на конкретные племена, народности и государства. Выделенные 
при этом в отдельные группы племена и народности кутиев / гутиев, касситов, эламитов, дравидов, суваров и шумеров трактуются, разумеется, опираясь на веские доводы и аргументы - как этнические компоненты или носители в той или иной степени формирующегося прототюркского языка.

Более того, эти же давно вымершие этносы татарским тюркологом исследуются и анализируются в сравнительном плане в контексте архаической идеологии и культуры, и полученные выводы при этом сближают и объединяют их с традиционной культурой тюркского мира. В ходе этих исследований автором выделены устойчивые этнические признаки, названные им этническими определителями и индикаторами. Самое главное, они позволили М. Бакирову роднить или отождествлять носителей этих признаков с тюркским этническим и этнокультурным социумом.

К таким этническим определителям, идущим из глубин истории, татарский тюрколог относит прежде всего отдельные мифологемы-мотивы символического характера, которые засвидетельствованы в традиционной культуре наших предков как доминирующие и системные признаки. Это, в частности, волк или волчица, выступавшие у тюркских племен и народов в различных ипостасях: и как прародитель-родоначальник племени, и как проводник, указывающий новые места для переселения или маршрут во время военных походов, и как кормилец-спасатель будущего вождя рода или племени. Исследователь истоки этого культа обнаруживает именно на Западе у вышеназванных неиндоевропейских народностей.

Второй ведущий мифологический образ, послуживший исследователю как этнический индикатор для выявления наших дальних предков, это большой и одноголовый крылатый змейсазаган. В отличие от вредоносного многоголового дракона, идущего из мифологии иранцев, такой образ возвеличивался и почитался у тюрков. Вообще, как установлено учеными многих поколений, индоевропейские народы, включая индоариев и иранцев, были змееборцами - яростными противниками культа змей. Причину того, что в христианской религии даже дьяволсатана выступает в обличии змеи, М. Бакиров видит именно во враждебном отношении индоевропейцев к этой рептилии. Исходя из высказывания русского слависта А. А. Потебни («мы считаем волка за другую форму мифологического змея»), татарский тюрколог рассматривает эти образы в одной упряжке. При этом он в древних культурах Ближнего Востока от волка- и змее- борцев резко отделяет почитателей (на деле зачинателей прототюркской мифологии) этих же мифологических животных.

Кроме данных мифологем и образов исследователь-тюрколог в качестве этнических определителей выдвигает еще несколько признаков, характерных именно для тюркской традиционной культуры. Это, в отличие от индоевропейских народов, предпочтение или возвеличивание левой стороны - стороны сердца и мужского пола (левая - мужская сторона юрты, привилегированное положение воинских должностей и воинов левого крыла, левосторонний запах одежды), далее - пещерное происхождение родоначальника племени или культ пещеры предков, кругообразная планировка ранних стоянок или поселений, своеобразные прически, специфическая еда (кумыс и конина). Эти признаки позволили исследователю путем накладывания на древние культуры Среднеземноморского бассейна нащупать и выделить (разумеется, совместно с языковыми реалиями) ранние племена и народности тюркского склада, в среде которых зарождалась и формировалась этнокультура предков.

Кстати, именно эти же показатели помогли исследователю подойти к сако-скифам и сарматам с новой позиции и видеть среди этнического массива их туранских и причерноморских пратюрков. Для подтверждения и подкрепления своего взгляда им же составлен и размещен дополнительный раздел - сако-скифо-сармато-тюркский словарь с общими лексемами.

Самостоятельную ценность представляют в работе разделы, посвященные хунно-гуннам и смежным с ними или появившимся после них древнетюркским народностям. Особый интерес вызывает доказательство тюркоязычности гуннов, подкрепленное достаточно емким словарем, собранным по крупицам из различных малоизвестных источников. Ранние тюрки Средней и Центральной Азии, а также Сибири в изложении М. Бакирова воспринимаются как преемники и потомки пришельцев с Запада, иначе говоря органически вписываются в ключевую его концепцию.

Еще одна принципиально важная область, что нашла весьма убедительное и объективное решение в монографии и которую хотелось бы выделить особо, это вопрос антропологии, связанный с характером физического типа наших предшественников и их преемников. В противовес предвзятому мнению о монголоидности хуннов и древних тюрков, которое проникло, оказывается, и в «Историю татар с древнейших времен» (Казань, 2002, т. 1), М. Бакиров изначальных тюрков и их преемников по большому счету 
относит к европеоидам, опираясь при этом на оставшийся до этого вне поля зрения историков малоизвестный коллективный труд В. А. Алексеева, И. Гохмана и Д. Тумэна.

Что касается монголоидности или монголоидной примеси у отдельных тюркоязычных народов, особенно на восточных окраинах, то эту особенность автор, ссылаясь на труды отдельных исследователей, связывает с проникновением и близким соприкосновением их предков с монголами и отчасти тунгусо-маньчжурами алтайского языкового круга.

В завершение хочется отметить, что М. Бакировым создан уникальный труд по этногенезу и этнической, этнокультурной истории тюркоязычного мира. Структура работы, методика исследований и использованные источники, литература, содержащие более 800 названий, а главное - полученные результаты, на наш взгляд, впечатляют! Хочется особо отметить, что удив- ляет терпение и выносливость автора этого фундаментального творения - немолодого уже исследователя, но мудрого и многостороннего специалиста. Ориенталистика ждала именно такого рыцаря науки, талантливого тюрколога, как профессор М. Бакиров.

\section{Список литературы}

Иллич-Свитыч В. М. Опыт сравнения ностратических языков. Сравнительный словарь. М.: Наука, 1971. $369 \mathrm{c}$.

\section{References}

Illich-Svitych V. M. (1971). Opyt sravneniia nostraticheskikh iazykov. Sravnitel'nyi slovar'. [Experience of Comparing Nostratic Languages. A Comparative Dictionary]. 369 p. Moscow, Nauka. (In Russian)

The article was submitted on 15.11.2020 Поступила в редакцию 15.11.2020

\author{
Азертюрк Тариел, \\ доктор биохимии, \\ учредитель, главный редактор, \\ журнал «The Turkic world - Türk dünjasi» и \\ «Babelon - Azerbaijan» (CШA), \\ США. Сиэтл \\ tarikatv@frontier.com
}

